\title{
A Case of COVID-19 Pregnancy Complicated with Hydrops Fetalis and Intrauterine Death
}

\author{
Daniela Eugenia Popescu ${ }^{1,2}(0)$, Andreea Cioca ${ }^{3, *}$, Cezara Muresan ${ }^{4,5}$, Dan Navolan ${ }^{5}$, Arina Gui ${ }^{4}$, Ovidiu Pop ${ }^{6}$, \\ Tamara Marcovici ${ }^{7}$, Constantin Ilie ${ }^{8}$, Marius Craina ${ }^{5}$ and Marioara Boia ${ }^{1}$
}

check for

updates

Citation: Popescu, D.E.; Cioca, A.; Muresan, C.; Navolan, D.; Gui, A.;

Pop, O.; Marcovici, T.; Ilie, C.;

Craina, M.; Boia, M. A Case of COVID-19 Pregnancy Complicated with Hydrops Fetalis and Intrauterine Death. Medicina 2021, 57, 667. https://doi.org/10.3390/ medicina57070667

Academic Editor: Stefano Aquaro

Received: 5 June 2021

Accepted: 25 June 2021

Published: 28 June 2021

Publisher's Note: MDPI stays neutral with regard to jurisdictional claims in published maps and institutional affiliations.

Copyright: (C) 2021 by the authors Licensee MDPI, Basel, Switzerland. This article is an open access article distributed under the terms and conditions of the Creative Commons Attribution (CC BY) license (https:/ / creativecommons.org/licenses/by/ $4.0 /)$.
1 Department of Neonatology, "Victor Babeş” University of Medicine and Pharmacy, Eftimie Murgu Sq. No.2, 300041 Timişoara, Romania; popescu.daniela@umft.ro (D.E.P.); marianaboia@yahoo.com (M.B.)

2 Department of Neonatology, Premiere Hospital, Regina Maria Health Network, Calea Aradului, No.113, 300645 Timişoara, Romania

3 Department of Pathology, Premiere Hospital, Regina Maria Health Network, Calea Aradului, No.113, 300645 Timişoara, Romania

4 Department of Obstetrics and Gynecology, Premiere Hospital, Regina Maria Health Network, Calea Aradului, No.113, 300645 Timişoara, Romania; muresan.maria@umft.ro (C.M.); arina_vra@yahoo.com (A.G.)

5 Department of Obstetrics and Gynecology, "Victor Babeş" University of Medicine and Pharmacy, Eftimie Murgu Sq. No.2, 300041 Timişoara, Romania; navolan.dan@umft.ro (D.N.); craina.marius@umft.ro (M.C.)

6 Department of Morphological Sciences, University of Oradea, Universitatii Street, No.1, 410087 Oradea, Romania; drovipop@gmail.com

7 Department of Pediatrics, First Pediatric Clinic, “Victor Babeş” University of Medicine and Pharmacy, Eftimie Murgu Sq. No.2, 300041 Timişoara, Romania; marcovici.tamara@umft.ro

8 Department of Neonatology, Regina Maria Health Network, Aristide Demetriade Street, No.1, 300088 Timisoara, Romania; constantinilie@umft.ro

* Correspondence: cioca.andreea19@gmail.com; Tel.: +40-722-244-330

Abstract: Coronavirus disease 2019 (COVID-19) has rapidly evolved into a worldwide pandemic causing a serious global public health problem. The risk of vertical transmission of SARS-CoV-2 is still debated, and the consequences of this virus on pregnant women and their fetuses remain unknown. We report a case of pregnancy complicated with hydrops fetalis that developed 7 weeks after recovery from a mild SARS-CoV-2 infection, leading to intrauterine death of the foetus. Evidence of SARS$\mathrm{CoV}-2$ placentitis was demonstrated by the presence of viral particles in the placenta identified by immunohistochemistry. As we excluded all possible etiological factors for non-immunologic hydrops fetalis, we believe that the fetal consequences of our case are related to vertical transmission of SARS-CoV-2 virus. To the best of our knowledge, this is the second reported case in the literature of COVID-19 infection complicated with hydrops fetalis and intrauterine fetal demise.

Keywords: COVID-19; coronavirus; SARS-CoV-2; pregnancy; vertical transmission; fetal death; hydrops fetalis; placenta

\section{Introduction}

Coronavirus disease 2019 (COVID-19) caused by severe acute respiratory syndrome coronavirus 2 (SARS-CoV-2) has rapidly evolved into a worldwide pandemic causing a serious global public health problem. Previous experience of pregnant women infected with other types of coronaviruses such as severe acute respiratory syndrome (SARS) and Middle East respiratory syndrome (MERS) suggests that pregnant women might be more vulnerable to severe SARS-CoV-2 infection than the general population [1,2].

The impact of SARS-CoV-2 infection in pregnant women is still debated, and new information is constantly being revealed. While there is no clear evidence of adverse effects on pregnancy in the first trimester, an increased prevalence of preterm labor and delivery was noticed in women infected with SARS-CoV-2 during the third trimester of pregnancy $[3,4]$. There were also other adverse outcomes described in pregnant women infected with COVID-19 such as premature ruptures of membranes, intrauterine fetal 
distress, intrauterine growth restriction, low birth weight, in utero fetal death, or premature neonatal death $[2,4]$. Moreover, some multistate surveillance studies performed in the USA have shown that the stillbirth rates increased from $<1 \%$ (before the pandemic) to $2.2-3 \%$ [5-7]. Although these data are alarming, the clinical outcomes of COVID-19 on pregnant woman and their fetuses are not fully documented, as many countries are still in the grips of the pandemic and our knowledge about this disease is based on individual case reports or limited cohorts. To establish the true effect of COVID-19 on pregnancy, complete data from larger studies are required.

In this paper, we report a case of pregnancy complicated with hydrops fetalis that developed 7 weeks after recovery from SARS-CoV-2 infection leading to intrauterine fetal demise in association with documented placental SARS-CoV-2 infection.

\section{Case Report}

A 27-year-old primigravida woman presented at 18 weeks' gestation with fever of $38.2^{\circ} \mathrm{C}$, taste and smell loss, dry cough, and fatigue. A transcriptase polymerase chain reaction (RT-PCR) of nasopharyngeal swab was positive for SARS-CoV-2. C and D vitamins were administered, along with Amoxicillin, Acetaminophen, and Enoxaparin for 14 days, then the patient was discharged home as her illness did not require hospitalization.

Consanguinity was denied and her past medical history was unremarkable. TORCH screen was negative, and thrombophilia tests were also negative.

A routine ultrasound examination (US) performed at 25 weeks' gestation revealed hydrops fetalis with skin edema and severe thoracic and abdominal effusion (Figure 1). As she was Rhesus (RhD) negative and her husband was positive, with negative anti-RH antibodies, a dose of Anti-D immunoglobulin was administrated. No anemia was detected during pregnancy. A thoracocentesis and amniocentesis were performed. Cytogenetic analysis revealed a normal female karyotype. Because the evolution did not improve, another thoracocentesis and a percutaneous in utero thoracoamniotic shunt was placed in the left hemithorax at 26 weeks' gestation (Figure 2). However, the evolution remained stationary, and at 28 weeks, the obstetric US confirmed fetal death.

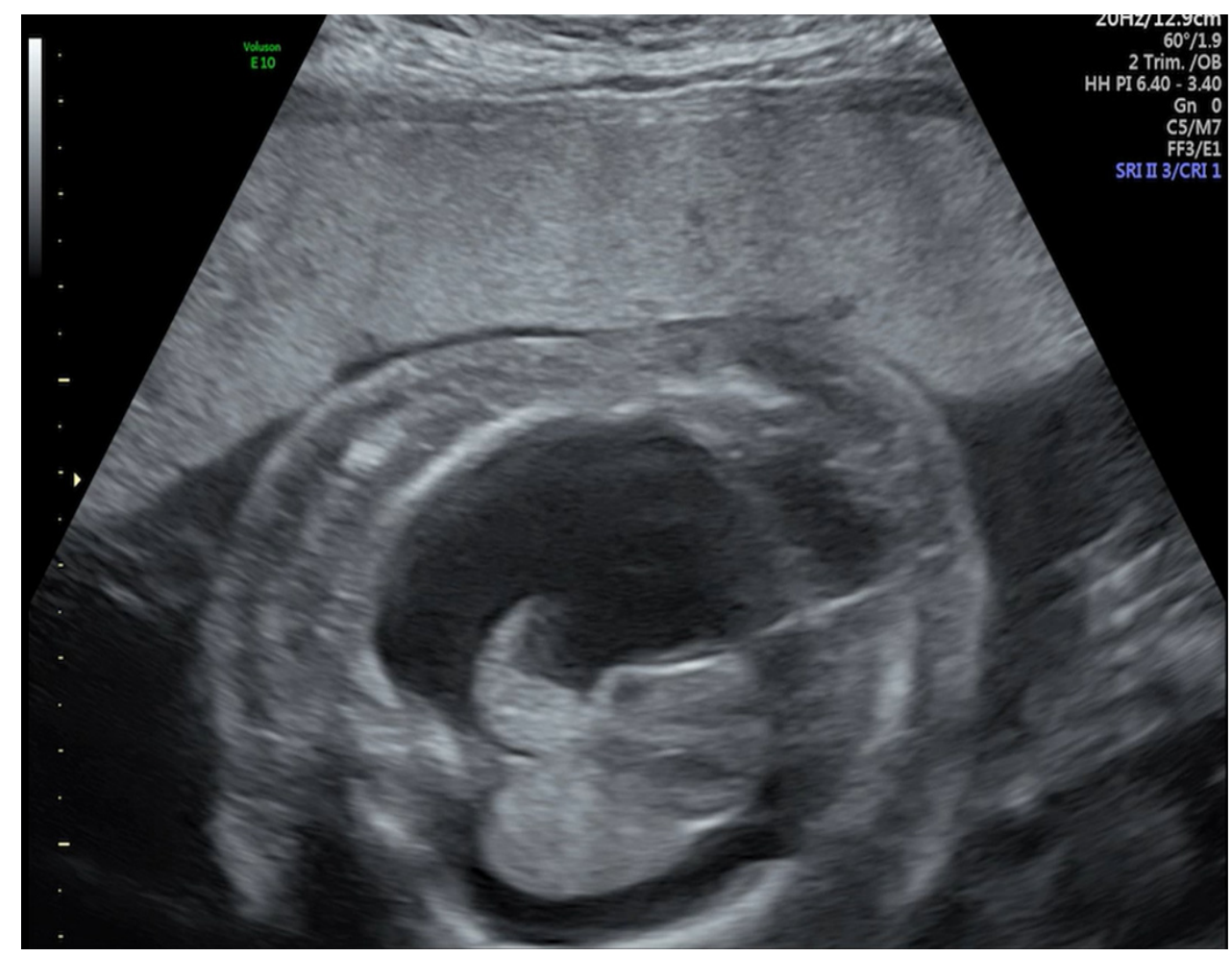

Figure 1. Transverse abdominal section of the thorax showing skin edema and thoracic effusion. 


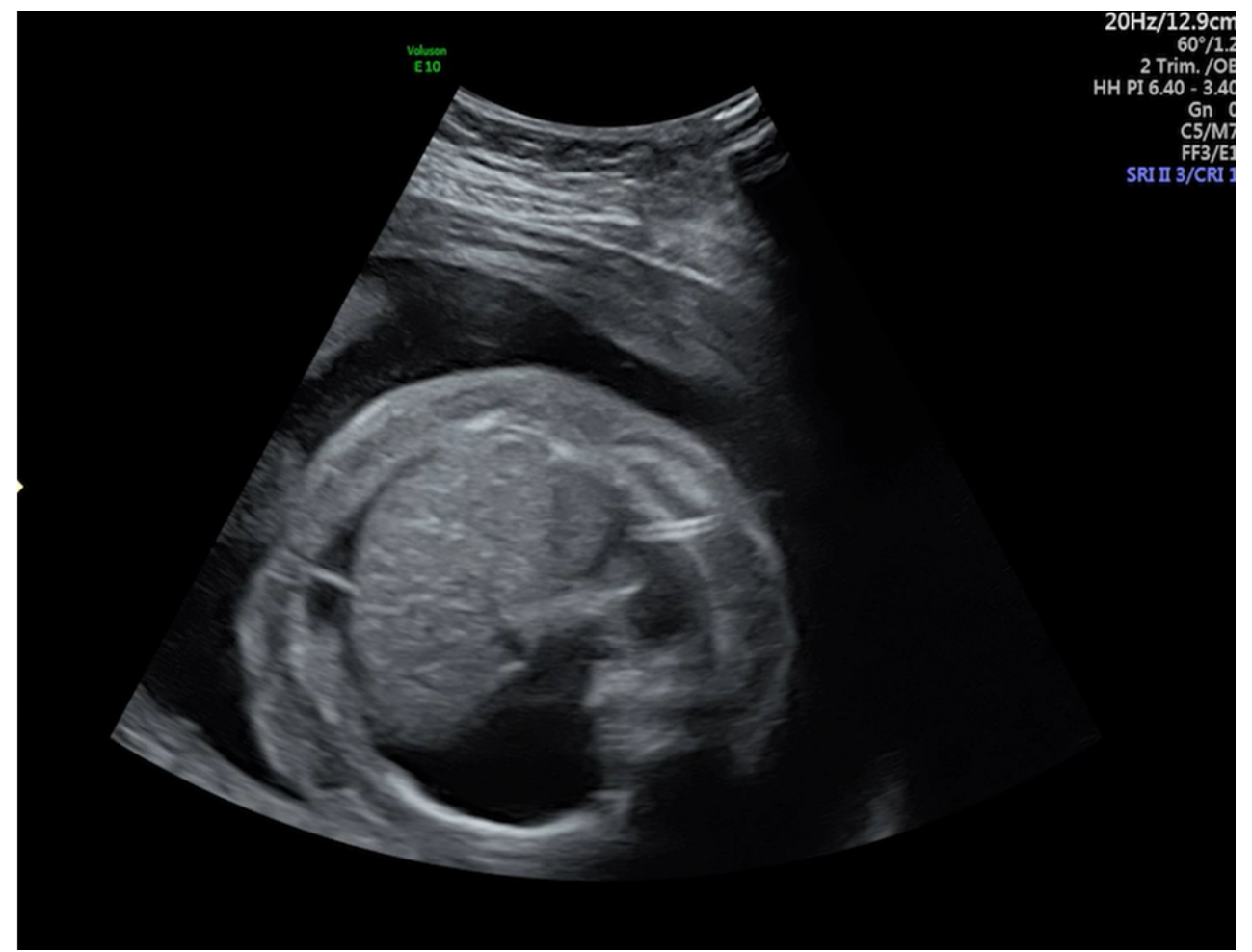

Figure 2. Transverse abdominal section revealing ascites and the presence of percutaneous thoracoamniotic shunt.

A stillborn fetus was delivered vaginally after $9 \mathrm{~h}$ of labor. The autopsy revealed a female fetus, appropriate for gestational age ( 28 weeks' gestation), with systemic edema (Figure 3). There was no evidence of external or internal malformations. The placenta weighed $751 \mathrm{~g}$ ( $>90$ th percentiles for 28 weeks' gestation) and presented a marginal cord insertion at $1 \mathrm{~cm}$ from the disc edge.

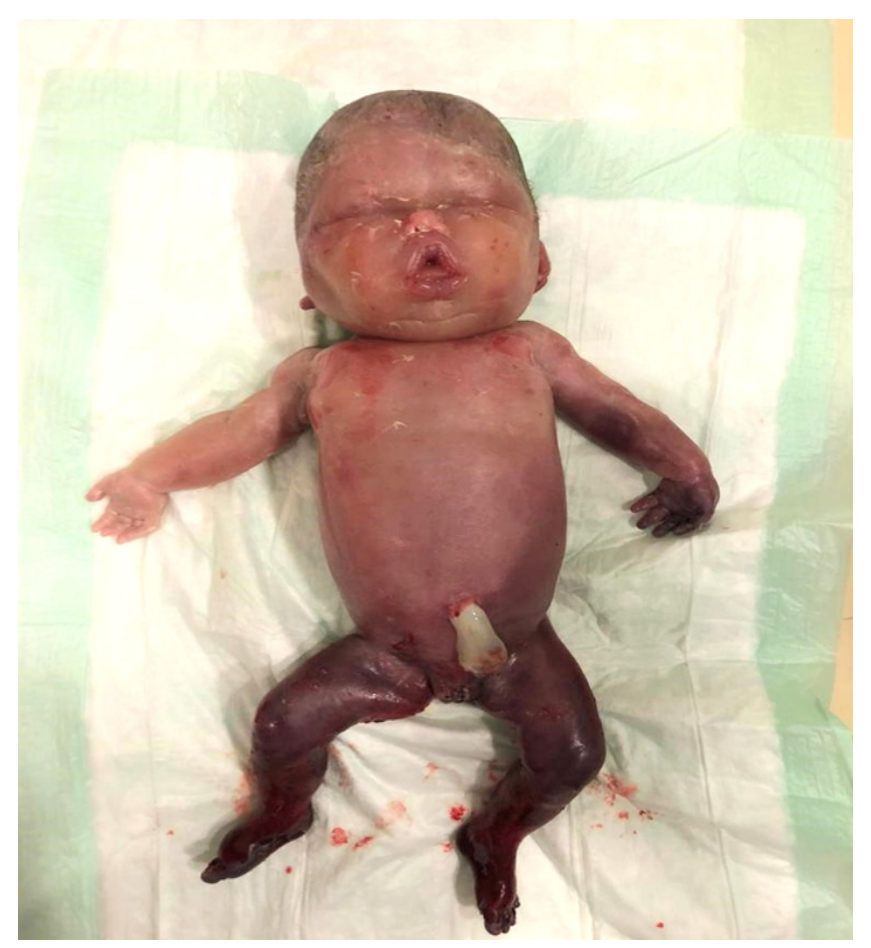

Figure 3. Macroscopy of the fetus showing generalized massive edema. 
Microscopic evaluation of the internal organs depicted a systemic thrombosis, with old and recent thrombi in the small and medium vessels. There were groups of villi with stromal hemorrhage and a mild acute inflammatory infiltrate was found in subchorionic space consistent with acute subchorionitis (maternal response stage 1 , grade 1 with no fetal response), (Figure 4A). Recent thrombi were identified in fetal circulation including umbilical vein (at the fetal edge), chorionic vessels, and stem villi vessels (Figure 4B). In addition, recent intervillous thrombi, perivillous fibrin deposition, and mixed inflammatory infiltrates composed of neutrophils and few monocytes were noted in the intervillous space (Figure 4C). Gram and periodic acid-Schiff staining of the placenta and culture did not demonstrate any bacterial or fungal infections. Immunohistochemistry with SARSCoV-2 nucleocapsid protein showed strong positivity of the trophoblast and fetal villous macrophages (Figure 4D). Fetal skin was sampled for the molecular karyotype (SNP array, Cytoscan 750KAffimetrix), which showed a normal female karyotype, arr(1-22,X)x2.

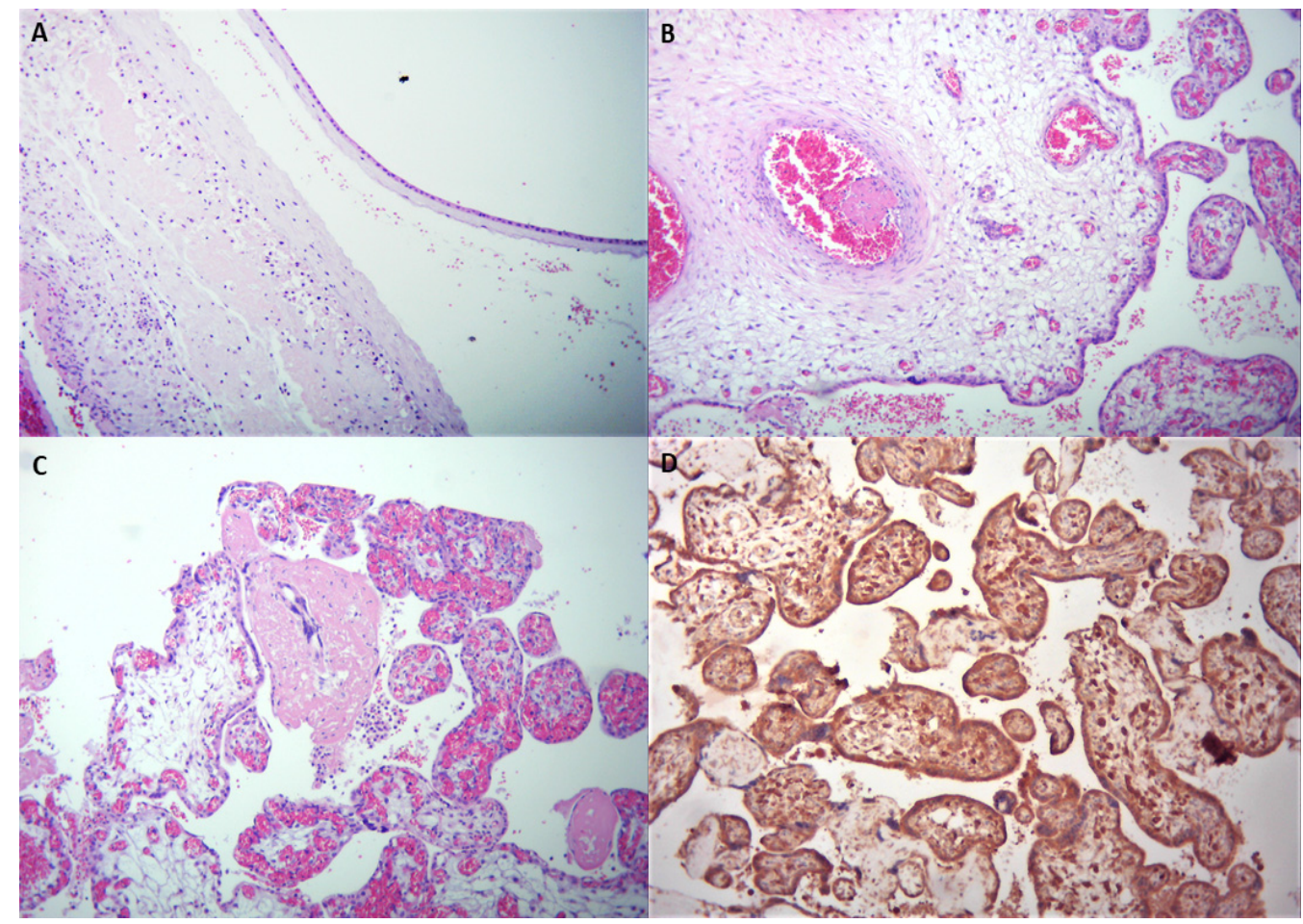

Figure 4. (A) Microscopy of the membranes showing a mild acute inflammatory infiltrate in the subchorionic space consistent with acute subchorionitis (H\&E staining, 10×). (B). Recent thrombus attached to the endothelium in a stem villi vessel (H\&E staining, 10 $\times$ ). (C). Placenta section revealing perivillous fibrin deposition and mild inflammatory infiltrate (H\&E staining, 10×). (D). Immunohistochemistry for SARS-CoV-2 protein showing strong positivity of the trophoblast and fetal villous macrophages, $10 \times$.

\section{Discussion}

Vertical transmission of SARS-CoV-2 is a rare event, with an estimated incidence of $1-3 \%$ of cases or even lower as reported by other authors [8,9]. Although, the mechanism of vertical transmission remains controversial, detection of SARS-CoV-2 in placental or membrane tissues by immunohistochemistry or molecular methods supports a scenario of vertical transmission of the virus $[8,10]$. A possible pathway for viral entrance is through the angiotensin-converting enzyme 2 (ACE2), a surface sensitive cell receptor for SARS-CoV-2, that showed an aberrant expression in human placentas. Another possible explanation for intrauterine SARS-CoV-2 infection is via maternal immune cells or, less commonly, during vaginal delivery [11]. 
Placental pathology findings from pregnant women with COVID-19 were previously described by many authors (Table 1), [12-20]. Poisson and Pierone identified placental lesions such as extensive fetal vascular malperfusion in a case of fetal demise from a woman with SARS-CoV-2 infection without any associated disease [12]. In a series of 20 cases, Baergen and Heller showed that fetal vascular malperfusion was the most common lesion in their cohort [13]. Menter et al. described features of villitis and malperfusion in a series of five cases and suggested that these histopathological changes may be related to an altered coagulative or microangiopathic state induced by COVID-19 [14]. In a recent study, inflammatory and thrombo-hemorrhagic alterations were the most frequent pathological changes in a series of ten placentas from women infected with COVID-19 [15]. Ferraiolo et al. identified placental alterations, and Birindwa et al. reported a case of a woman infected with SARS-CoV-2 that gave birth to a newborn also infected with COVID-19. The baby died 5 days after delivery and histopathological examination revealed thrombotic vasculopathy of both placenta and umbilical cord [16]. In line with these reports, we found recent and organized thrombi in fetal circulation including the umbilical vein, chorionic and stem villi vessels but also in the small and medium vessels of the fetal internal organs. We also identified a mild acute inflammatory infiltrate in subchorionic space consistent with acute subchorionitis and a mixed intervillitis. In a series of five cases of fetal demise in women with mild or moderate forms of COVID-19 infection, Richtmann et al. reported acute chorioamnionitis in five cases and mixed intervillitis/villitis in two of them [17]. Baud et al. described a mixed inflammatory infiltrate in the subchorionic space and intervillous fibrin deposition in a case of miscarriage during the second trimester in a pregnant woman with COVID-19 [18]. It is well known that COVID-19 is associated with a thrombo-inflammatory state, and thromboses in human placenta were already documented $[15,16,19]$. These observations suggest that fetal vascular thrombosis and inflammatory changes may represent a histological marker of COVID-19 placental infection. Moreover, these data are supported by the presence of viral particles in the placenta identified by immunohistochemistry $[8,10,11]$. In the present case, strong positive staining for SARS-CoV-2 was noted in both trophoblast and fetal villous macrophages. We believe that in our case, the placental inflammation was linked to the viral infection; thus, these findings represent a SARS-CoV-2 placentitis.

A causal relation between COVID-19 and non-immune hydrops fetalis has not been yet demonstrated. However, a recent publication described a transitory fetal skin edema associated with polyhydramnios developed after recovery from a mild SARS-CoV-2 infection of the mother. These fetal changes presented a spontaneous resolution in utero, and no abnormalities were found in the newborn [21]. Garcia-Manau et al. reported two cases of fetal transient skin edema in pregnant women with COVID-19 in their second trimester of pregnancy. In these cases, the fetal skin edema appeared when the mothers were positive for COVID-19 infection and resolved when maternal SARS-COV-2 RT-PCR test results became negative [22]. Shende et al. described a case of first trimester asymptomatic SARS-CoV-2 infection complicated with hydrops fetalis and intrauterine fetal demise. In their case, viral RNA was identified in the amniotic fluid, and the $S$ proteins were detected in the fetal membranes 5 weeks after the mother recovered from SARS-CoV-2 infection, concluding that hydrops fetalis and intrauterine fetal demise were caused by the congenital transmission of COVID-19 [23]. Similarly with their case, we found evidence of SARS-CoV-2 placentitis demonstrated by the presence of viral particles in the placenta identified by immunohistochemistry. As we excluded all possible etiological factors for non-immunologic hydrops fetalis, we believe that the fetal consequences of our case are related to vertical transmission of the COVID-19 virus. 
Table 1. Placental pathology in COVID-19 positive mothers.

\begin{tabular}{|c|c|c|c|}
\hline \multirow{2}{*}{ Study } & \multirow{2}{*}{ GA } & \multicolumn{2}{|c|}{ Histopathological Findings } \\
\hline & & FVM & Other Findings \\
\hline $\begin{array}{l}\text { Poisson et al. } \\
\text { [12] }\end{array}$ & 35 weeks & $\begin{array}{l}\text { Thrombosis, } \\
\text { Avascular villi }\end{array}$ & $\begin{array}{l}\text { Acute chorionitis, } \\
\text { Maternal vascular } \\
\text { malperfusion }\end{array}$ \\
\hline $\begin{array}{l}\text { Baergen et al. } \\
\text { [13] }\end{array}$ & 33 weeks-40 weeks & $\begin{array}{c}\text { Thrombosis, Fibrin } \\
\text { deposition, } \\
\text { Karyorrhexis, } \\
\text { Chorangiosis }\end{array}$ & $\begin{array}{l}\text { Maternal vascular } \\
\text { malperfusion } \\
\text { Intervillous thrombus, } \\
\text { Focal increase in } \\
\text { fibrin }\end{array}$ \\
\hline $\begin{array}{l}\text { Menter et al. } \\
{[14]}\end{array}$ & 39 weeks-41 weeks & $\begin{array}{c}\text { Thrombosis, } \\
\text { Avascular villi, } \\
\text { Chorangiosis, } \\
\text { Delayed villous } \\
\text { maturation }\end{array}$ & $\begin{array}{l}\text { Chorioamnionitis, } \\
\text { Chronic vilittis, } \\
\text { Subchorionitis, } \\
\text { Chronic deciduitis, } \\
\text { Maternal vascular } \\
\text { malperfusion }\end{array}$ \\
\hline $\begin{array}{l}\text { Bertero et al. } \\
\text { [15] }\end{array}$ & 32 weeks-40 weeks & $\begin{array}{c}\text { Thrombosis, } \\
\text { Chorangiosis, } \\
\text { Accelerated } \\
\text { maturation, } \\
\text { Fibrin deposition, } \\
\text { Avascular villi }\end{array}$ & $\begin{array}{l}\text { Chronic villitis, } \\
\text { Intervillous } \\
\text { hematoma, } \\
\text { Maternal vascular } \\
\text { malperfusion }\end{array}$ \\
\hline $\begin{array}{c}\text { Birindwa et al. } \\
{[16]}\end{array}$ & 34 weeks & $\begin{array}{l}\text { Thrombosis, } \\
\text { Chorangiosis }\end{array}$ & \\
\hline $\begin{array}{c}\text { Richtmann et al. } \\
\text { [17] }\end{array}$ & 21 weeks-38 weeks & Fibrin deposition & $\begin{array}{l}\text { Chorioamnionitis, } \\
\text { Chronic villitis, } \\
\text { Acute deciduitis }\end{array}$ \\
\hline $\begin{array}{l}\text { Baud et al. } \\
\text { [18] }\end{array}$ & 19 weeks & & $\begin{array}{l}\text { Subchorionitis, } \\
\text { Funisitis }\end{array}$ \\
\hline $\begin{array}{c}\text { Shanes et al. } \\
\text { [19] }\end{array}$ & 33 weeks-40 weeks & $\begin{array}{c}\text { Fetal vessel mural } \\
\text { fibrin, } \\
\text { Avascular villi, } \\
\text { Delayed villous } \\
\text { maturation, } \\
\text { Chorangiosis }\end{array}$ & $\begin{array}{l}\text { Maternal vascular } \\
\text { malperfusion }\end{array}$ \\
\hline $\begin{array}{c}\text { Ferraiolo et al. } \\
\text { [20] }\end{array}$ & & $\begin{array}{l}\text { Microchorangiosis, } \\
\text { Fibrin deposition }\end{array}$ & $\begin{array}{l}\text { Subchorionitis, } \\
\text { Intervillous } \\
\text { hemorrhages }\end{array}$ \\
\hline
\end{tabular}

GA, weeks of gestation; FVM, fetal vascular malperfusion.

To conclude, we reported a case with documented placental SARS-CoV-2 infection associated with fetal vascular thrombosis. To the best of our knowledge, this is the second reported case in literature of COVID-19 infection complicated with hydrops fetalis and intrauterine fetal demise. More data on pregnant women infected with COVID 19 and their fetuses are needed to create guidelines for clinical practice in order to prevent potential negative outcomes and fetal complications. Until more definitive answers are available, increased surveillance of pregnant women and their fetuses is needed.

Author Contributions: Conceptualization, A.C. and D.E.P.; methodology, T.M.; software, A.G.; validation, M.C., D.N. and M.B.; formal analysis, C.M.; investigation, A.G.; resources, O.P.; data curation, T.M.; writing - original draft preparation, A.C.; writing—review and editing, M.B.; visualization, C.M.; supervision, O.P.; project administration, C.I.; funding acquisition, D.E.P. All authors have read and agreed to the published version of the manuscript.

Funding: This research received no external funding. 
Institutional Review Board Statement: The study was conducted according to the guidelines of the Declaration of Helsinki and approved by the Ethics Committee of Premiere Private Hospital (protocol code 326/31.03.2021).

Informed Consent Statement: Written informed consent has been obtained from the patient to publish this paper.

Conflicts of Interest: The authors declare no conflict of interest.

\section{References}

1. Di Mascio, D.; Khalil, A.; Saccone, G.; Rizzo, G.; Buca, D.; Liberati, M.; Vecchiet, J.; Nappi, L.; Scambia, G.; Berghella, V.; et al. Outcome of coronavirus spectrum infections (SARS, MERS, COVID-19) during pregnancy: A systematic review and meta-analysis. Am. J. Obstet. Gynecol. MFM 2020, 2, 100107. [CrossRef]

2. Schwartz, D.A.; Graham, A.L. Potential Maternal and Infant Outcomes from (Wuhan) Coronavirus 2019-nCoV Infecting Pregnant Women: Lessons from SARS, MERS, and Other Human Coronavirus Infections. Viruses 2020, 12, 194. [CrossRef]

3. Yan, J.; Guo, J.; Fan, C.; Juan, J.; Yu, X.; Li, J.; Feng, L.; Li, C.; Chen, H.; Qiao, Y.; et al. Coronavirus disease 2019 in pregnant women: A report based on 116 cases. Am. J. Obstet. Gynecol. 2020, 223, 111.e1-111.e14. [CrossRef] [PubMed]

4. Schwartz, D.A.; Dhaliwal, A. Infections in pregnancy with COVID-19 and other respiratory RNA virus diseases are rarely, if ever, transmitted to the fetus: Experiences with coronaviruses, HPIV, HMPV RSV, and Influenza. Arch. Pathol. Lab. Med. 2020. [CrossRef] [PubMed]

5. Delahoy, M.J.; Whitaker, M.; O’Halloran, A.; Chai, S.J.; Kirley, P.D.; Alden, N.; Kawasaki, B.; Meek, J.; Yousey-Hindes, K.; Anderson, E.J.; et al. Characteristics and Maternal and Birth Outcomes of Hospitalized Pregnant Women with LaboratoryConfirmed COVID-19-COVID-NET, 13 States, 1 March-22 August 2020. MMWR Morb. Mortal. Wkly. Rep. 2020, 69, 1347-1354. [CrossRef] [PubMed]

6. Panagiotakopoulos, L.; Myers, T.R.; Gee, J.; Lipkind, H.S.; Kharbanda, E.O.; Ryan, D.S.; Williams, J.T.B.; Naleway, A.L.; Klein, N.P.; Hambidge, S.J.; et al. SARS-CoV-2 Infection Among Hospitalized Pregnant Women: Reasons for Admission and Pregnancy Characteristics-Eight U.S. Health Care Centers, 1 March-30 May 2020. MMWR Morb. Mortal. Wkly. Rep. 2020, 69, 1355-1359. [CrossRef]

7. CDC. Stillbirth Homepage. Data and Statistics. Available online: https://www.cdc.gov/ncbddd/stillbirth/facts.html (accessed on 11 September 2020).

8. Facchetti, F.; Bugatti, M.; Drera, E.; Tripodo, C.; Sartori, E.; Cancila, V.; Papaccio, M.; Castellani, R.; Casola, S.; Boniotti, M.B.; et al. SARS-CoV2 vertical transmission with adverse effects on the newborn revealed through integrated immunohistochemical, electron microscopy and molecular analyses of Placenta. EBioMedicine 2020, 59, 102951. [CrossRef]

9. Shook, L.L.; Collier, A.Y.; Goldfarb, I.T.; Diouf, K.; Akinwunmi, B.O.; Young, N.; Brown, A.; Hacker, M.R.; Kaimal, A.M.; Gray, K.J.; et al. Vertical transmission of SARS-CoV-2: Consider the denominator. Am. J. Obstet. Gynecol. MFM 2021, $28,100386$. [CrossRef]

10. Linehan, L.; O'Donoghue, K.; Dineen, S.; White, J.; Higgins, J.R.; Fitzgerald, B. SARS-CoV-2 placentitis: An uncommon complication of maternal COVID-19. Placenta 2021, 104, 261-266. [CrossRef]

11. Komine-Aizawa, S.; Takada, K.; Hayakawa, S. Placental barrier against COVID-19. Placenta 2020, 99, 45-49. [CrossRef]

12. Poisson, T.M.; Pierone, G., Jr. Placental pathology and fetal demise at 35 weeks of gestation in a woman with SARS-CoV-2 infection: A case report. Case Rep. Women's Health 2021, 30, e00289. [CrossRef] [PubMed]

13. Baergen, R.N.; Heller, D.S. Placental pathology in covid-19 positive mothers: Preliminary findings. Pediatr. Dev. Pathol. 2020, 23, 177-180. [CrossRef] [PubMed]

14. Menter, T.; Mertz, K.D.; Jiang, S.; Chen, H.; Monod, C.; Tzankov, A.; Waldvogel, S.; Schulzke, S.M.; Hösli, I.; Bruder, E. Placental Pathology Findings during and after SARS-CoV-2 Infection: Features of Villitis and Malperfusion. Pathobiology 2021, 88, 69-77. [CrossRef]

15. Bertero, L.; Borella, F.; Botta, G.; Carosso, A.; Cosma, S.; Bovetti, M.; Carosso, M.; Abboma, G.; Collemi, G.; Papotti, M.; et al. Placenta histopathology in SARS-CoV-2 infection: Analysis of a consecutive series and comparison with control cohorts. Virchows Arch. 2021, 1-14. [CrossRef]

16. Birindwa, E.K.; Mulumeoderhwa, G.M.; Nyakio, O.; Mbale, G.M.; Mushamuka, S.Z.; Materanya, J.M.; Kahasha, P.M.; Bisimwa, Y.K.; Kampara, F.M.; Irenge, J.M.; et al. A case study of the first pregnant woman with COVID-19 in Bukavu, eastern Democratic Republic of the Congo. Matern. Health Neonatol. Perinatol. 2021, 20, 7. [CrossRef]

17. Richtmann, R.; Torloni, M.R.; Oyamada Otani, A.R.; Levi, J.E.; Crema Tobara, M.; de Almeida Silva, C.; Dias, L.; Miglioli-Galvao, L.; Martins Silva, P.; Macoto Kondo, M. Fetal deaths in pregnancies with SARS-CoV-2 infection in Brazil: A case series. Case Rep. Women's Health 2020, 27, e00243. [CrossRef]

18. Baud, D.; Greub, G.; Favre, G.; Gengler, C.; Jaton, K.; Dubruc, E. Second-trimester miscarriage in a pregnant woman with SARS-CoV-2 infection. JAMA J. Am. Med. Assoc. 2020, 323, 2198-2200. [CrossRef] [PubMed]

19. Shanes, E.D.; Mithal, L.B.; Otero, S.; Azad, H.A.; Miller, E.S.; Goldstein, J.A. Placental Pathology in COVID-19. Am. J. Clin. Pathol. 2020, 154, 23-32. [CrossRef] 
20. Ferraiolo, A.; Barra, F.; Kratochwila, C.; Paudice, M.; Vellone, V.G.; Godano, E.; Varesano, S.; Noberasco, G.; Ferrero, S.; Arioni, C. Report of Positive Placental Swabs for SARS-CoV-2 in an Asymptomatic Pregnant Woman with COVID-19. Medicina 2020, 56, 306. [CrossRef]

21. Martínez-Varea, A.; Desco-Blay, J.; Monfort, S.; Hueso-Villanueva, M.; Perales-Marín, A.; Diago-Almela, V.J. Transitory Fetal Skin Edema in a Pregnant Patient with a Mild SARS-CoV-2 Infection. Case Rep. Obstet. Gynecol. 2021, 16, 5552877. [CrossRef]

22. Garcia-Manau, P.; Garcia-Ruiz, I.; Rodo, C.; Sulleiro, E.; Maiz, N.; Catalan, M.; Fernández-Hidalgo, N.; Balcells, J.; Antón, A.; Carreras, E.; et al. Fetal Transient Skin Edema in Two Pregnant Women With Coronavirus Disease 2019 (COVID-19). Obstet. Gynecol. 2020, 136, 1016-1020. [CrossRef] [PubMed]

23. Shende, P.; Gaikwad, P.; Gandhewar, M.; Ukey, P.; Bhide, A.; Patel, V.; Bhagat, S.; Bhor, V.; Mahale, S.; Gajbhiye, R.; et al. Persistence of SARS-CoV-2 in the first trimester placenta leading to transplacental transmission and fetal demise from an asymptomatic mother. Hum. Reprod. 2021, 36, 899-906. [CrossRef] [PubMed] 